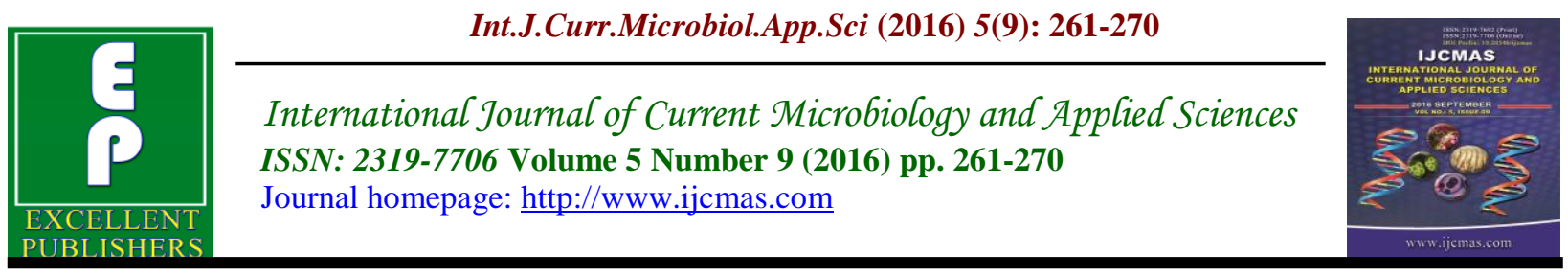

Original Research Article

http://dx.doi.org/10.20546/ijcmas.2016.509.029

\title{
Identification and Biochemical Analysis of Microorganisms involved in the Fermentation of Kawal-A Traditional Fermented Sicklepod Leaves (Senna obtusifolia)
}

\author{
Abakar Idriss Lawane, Savadogo Aly*, Tapsoba François, Guira Flibert and Traore Yves \\ LABIA, Centre de Recherche en Sciences Biologique, Alimentaire et Nutritionnelle \\ (CRSBAN), Université Ouaga 1 Pr Joseph KI-ZERBO, Burkina Faso \\ *Corresponding author
}

\section{Keywords}

Kawal, chad, Bacillus, biochemical composition, characterization, PCR.

Article Info

Accepted:

13 August 2016

Available Online:

10 September 2016

\section{A B S T R A C T}

This study was carried out to determine, using microbial and chemical standards methods, the chemical composition, the quality and the major microorganisms of Kawal, fermented Senna obtusifolia leaves consumed as a substitute of meat or an appetizing agent in Chad. The $\mathrm{pH}$ was ranged between $5.82 \pm 0.19$ and $7.22 \pm$ 0.31 , the acidity between $0.31 \pm 0.00$ and $0.54 \pm 0.00 \%$, the dry matter content, $90.00 \pm 0.00$ and $92.46 \pm 0.43 \%$, the protein content, $15.52 \pm 0.09$ and $22.06 \pm$ $0.07 \%$,the ash content, $17.12 \pm 0.01$ and $19.3 \pm 0.00 \%$. The Total viable counts were between $9.7 \times 10^{9}$ and $2.7 \times 10^{11} \mathrm{CFU} / \mathrm{g}$; Bacillus sp., $3.7 \times 10^{8}$ and $9.1 \times$ $10^{9} \mathrm{CFU} / \mathrm{g}$, lactic acid bacteria, $1.1 \times 10^{2}$ and $2.8 \times 10^{6} \mathrm{CFU} / \mathrm{g}$; Staphylococcus sp., $1.5 \times 10^{3}$ and $3.7 \times 10^{7} \mathrm{CFU} / \mathrm{g}$, Micrococcus sp. $<10 \mathrm{CFU} / \mathrm{g}$ and $7.4 \times 10^{4} \mathrm{CFU} / \mathrm{g}$. Yeasts and molds as well as enterobacteria were less represented or absent in most samples analyzed. Bacillus strains, the dominant microflora were isolated and grouped into 15 groups. Their biochemical and molecular characterizationshowed a high diversity involved in the fermentationof kawal among them $B$. subtilis, $B$. licheniformis, B. pumilus, and B. amyloliquefaciens were identified.

\section{Introduction}

Fermented foods play an important role in providing food security, enhancing livelihoods and improving the nutrition and social well-being of millions of people around the world (Battcock, 1998). They also play a very important role in the socioeconomics of developing countries. Fermented foods are generally produced from plant or animal-based raw materials in combination with fungi or bacteria, which are either present in the natural environment, or added intentionally by human to obtain the desirable end-products (Law et al., 2011). Fermentation is a process that has been used by humans for thousands of years, as a method of food transformation and preservation. Fermentation improves nutritive value, safety, hygienic and organoleptic quality of the food and detoxification of anti-nutrient factors (AFNOR, 1986; Law et al., 2011; Nnam and Obiakor, 2003; Nout et al., 1987; 
Sawadogo-Lingani et al., 2008). Each nation has its own types of fermented food, representing the staple diet and the raw ingredients available in that particular place (Egwim Evans et al., 2013). In Africa, the art of fermentation is widespread including the processing of fermented cereals, legumes, and tubers used for the production of fermented foods, and other carbohydrate sources to yield alcoholic and non-alcoholic beverages. The fermented cereals are dominated by Lactic Acid Bacteria (LAB) associated with yeast. In other African indigenous alkaline-fermented foods, Bacillus spis one of the microorganisms that dominates, with their major proteolytic activityto hydrolyze proteins into amino acidsand ammonia.

Senna alata L., Senna hirsuta L. and Senna obtusifolia L. are the woody annual herbs orundershrub herbs which are native to Africa as medicinal species with active functions and therapeutic agents (Ayo 2010). S. obtusifolia leaves, seeds, roots and flower are used in folk medicine, primarily in Asia. It is believed to possess a laxative effect like $S$. alata compared to $S$. hirsuta as well as to be beneficial for the eyes (Oliver 2005, Sofowora 2008). S. obtusifoliais used as folk remedy, the seeds are often roasted, then boiled in water to produce a tea but in Java and in South-East Asia (Sofowora 2008). Within the Chad and the western Sudan, Kawal is fermented leaves of Senna obtusifolia, produced and consumed as a substitute of meat or an appetizing agent (Mbaiguinam, 2005). Kawal was found to be rich in proteins $(30.20 \%)$, Carbohydrate (22.68\%), Oil (4.12\%)and minerals (18.74\%) (Osman et al., 2010). The production process is still naturally and traditionally with the rudimentary equipment. However, contamination of the products may take place at all stages of production by undesirable microorganisms from the human and animal reservoir as well as other environmental. It is necessary to determine the biochemical and microbiological quality and to isolate and select Bacillus strains responsible for kawal fermentation which can be used as starter cultures, for their essential role in most fermented food, for their ability to produce various antimicrobial compounds promoting probiotic properties (Temmerman et al.,2003).

This study was performed to investigate the microbiology and chemical content of fermented leaves of $S$. obtusifolia and characterize the dominant microflora of these products in order to improve safety and stability of the product.

\section{Materials and Methods}

\section{Sampling}

Twenty (20) Kawal samples were purchased from the markets of Abéché, Bokoro, Mandelia and N'Djamena in Chad. 200g of each sample were placed separately in a sterile plastic sampling bag and transported immediately to the laboratory, stored under refrigeration until analysis.

\section{Physico-chemical analysis}

The physico-chemical properties of the kawal samples were determined by using standard methods of analysis. The $\mathrm{pH}$ was measured using a digital $\mathrm{pH}$-meter (MettlerToledo) calibrated with $\mathrm{pH} 4$ and 7 buffers at $25^{\circ} \mathrm{C}$ according to AOAC (Feldsine et al., 2002). Moisture content was determined by the difference between the known weight of kawal samples and the determined weight of the total solid after evaporating the liquid component of the kawal samples on a hot plate at $105^{\circ} \mathrm{C}$ for 3 hours (Helrich, 1990). The titratable acidity was determined by 
titration with $0.1 \mathrm{~N} \mathrm{NaOH}$, using $1 \%$ phenolphthalein as the indicator (AFNOR, 1986). The result was expressed as g lactic acid $/ 100 \mathrm{~g}$ of sample. The ash content was determined by incineration of the sample placed in the muffle furnace at $550{ }^{\circ} \mathrm{C}$ for 8 hours (AOCS, 1990; Feldsine et al., 2002; Helrich, 1990) and the crude protein content by kjedahl method (AOCS, 1990).

\section{Microbiological analysis}

Ten (10) g of representative kawal sample were placed in a sterile stomacher bag containing $90 \mathrm{~mL}$ of $0.1 \%$ peptone sterile physiological saline solution $(0.9 \% \mathrm{NaCl})$ and homogenized. Appropriate dilutions of the sample homogenates were prepared in sterile physiological saline solution $(0.9 \%$ $\mathrm{NaCl})$ and inoculated in duplicate in growth specific media to estimate microbial counts.

The Total viable were counted on Plate Count Agar (PCA), after 24 hours of incubation at $30^{\circ} \mathrm{C}$ under aerobic conditions.

Lactic acid bacteria were enumerated and isolated using De Mann, Rogosa and Sharpe (MRS) agar(Sigma-Aldrich, USA) after 2472 hours of incubation at $30^{\circ} \mathrm{C}$ anaerobically for 24-72 hours.

Yeasts and molds were enumerated on Sabouraud Dextrose Agar (Biokar, France) after 3-5 days of incubation at $30^{\circ} \mathrm{C}$, under aerobic conditions. Micrococcus sp, and Staphylococcus sp, were enumerated and isolated on Mannitol Salt Agar (MSA) (Biokar, France)after 24 hours of incubation at $37^{\circ} \mathrm{C}$, under aerobic conditions. Enterobacteriaceae were determined on violet red bile dextrose agar (VRBDA) (Biokar, France) after incubation at $37{ }^{\circ} \mathrm{C}$ for 24 hours.

Bacillus species were isolated over Plate Count Agar (PCA) (Biokar, France) following heat treatment of the homogenate $\left(80{ }^{\circ} \mathrm{C}\right.$ for $\left.10 \mathrm{~min}\right)$ and incubation at $37^{\circ} \mathrm{C}$ for 24 hours.

\section{Isolation and purification of Bacillus strains}

A total of 108 bacterial strains were randomly picked from petri dishes according to the colony characteristics, shape size, structure, elevation, edge and color. The isolated strains were sub-cultured onto tryptone Soy Agar (TSA) by the streaking method. Colonies with the same shape and appearance on agar were isolated for the morphological and biochemical characterization.

\section{Biochemical and physiological identification}

All the pure cultures isolates obtained by repeated streaking were observed for cell morphology, motility, and Gram staining, using microscope. Then the isolates were subjected to biochemical tests such as Oxidase, Catalase, oxidation/fermentation of glucose, and gelatin hydrolyses, nitrate reduction, amylase, lecithinase productions following the criteria described in the Bergey's Manual of Systematic Bacteriology (Holt et al., 1994), for identification to genus or species level. The presumptive Bacillus species were confirmed by endospore forming and catalase test. In parallel, the commercial API 20E (bio, France) and digitized probabilistic method for Bacillus identification were also used(Guech-Lamari and Kirane-Gacemi, 2012).

\section{Molecular identification}

\section{DNA isolation and purification}

The QIAamp DNA stool minikit (Qiagen, France S.A.) and protocol technics were 
used according to manufacturer's recommendation to isolate andpurify genomic DNA from bacterial cultures. The purified genomic DNA was qualified by electrophoresis through an agarose gel $(1 \%$ $(\mathrm{w} / \mathrm{v}))$.

\section{Amplification and Electrophoresis}

Tow group-specific primer pair were used for the identification of Bacillus strains. The first primers $\left(\mathrm{B}-\mathrm{K} 1 / \mathrm{F} \quad\left\{5^{\prime}-\mathrm{TCACCAAGGC}\right.\right.$ RACGATGCG-3' $\}$ and B-K1/R1 \{5'CGTATTCACCGCGGCATG-3' $\}$ ) used to amplify a specific sequence of $16 \mathrm{~S}$ rDNA from all Bacillus genus have been developed by Wu et al. (2006).

The second primers used for PCR were Bsub5F \{5'- AAG TCG AGC GGA CAG ATG G-3' $\}$ and Bsub3R $\left\{5^{\prime}-\right.$ CCA GTT TCC AAT GAC CCT CCC C-3'\} to amplify a specific sequence of $16 \mathrm{~S}$ rDNA from Bacillus Subtilis group(Table 1).

For The amplification of the bacterial DNA, $25 \mu \mathrm{L}$ of reaction mixture containing 9.87 $\mu \mathrm{L}$ of sterile deionised water, $5 \mu \mathrm{L}$ of PCR buffer (5X Green GoTaq Promega Corporation), $1.5 \mu \mathrm{L}$ of $25 \mathrm{mM} \mathrm{MgCl}_{2}$ (Promega Corporation), $0.5 \mu \mathrm{L}$ of $10 \mathrm{mM}$ dNTP (Promega), 1.5 $\mu \mathrm{L}$ of forward and reverse primers, $0.13 \mu \mathrm{L}$ (5U) of Taq DNA polymerase (Promega,) and $5 \mu \mathrm{L}$ of DNA. The cycling program was started with an initial denaturation at $95^{\circ} \mathrm{C}$ for $2 \mathrm{~min}$ followed by 30 cycles of denaturation at $95^{\circ} \mathrm{C}$ for $45 \mathrm{~s}$, annealing at $58{ }^{\circ} \mathrm{C}$ for $45 \mathrm{~s}$ and elongation at $72{ }^{\circ} \mathrm{C}$ for $1 \mathrm{~min}$. The PCR mixture and thermal cycling used for the amplification of Bacillus Subtilis group DNA was the same as for Bacillus genus except for the annealing temperature it was at $60{ }^{\circ} \mathrm{C}$ for $45 \mathrm{~s}$. After complete reaction mixture were cooled to $4{ }^{\circ} \mathrm{C} .7 \mu \mathrm{L}$ of the amplified products of PCR were analyzed by electrophoresis in $1 \%(\mathrm{w} / \mathrm{v})$ agarose gels stained with ethidium bromide $(0.5 \mathrm{mg}$ $/ \mathrm{mL}$ ). The gels were visualized with an Ultraviolet Illuminator(TFX - 20.C).

\section{Results and Discussion}

The chemical parameters of collected kawal samples analysed were presented in table 2.

\section{pH and Titratable acidity}

The $\mathrm{pH}$ values were ranged between $5.87 \pm$ 0.19 and $7.22 \pm 0.31$ and titratable acidity (as lactic acid) $0.31 \pm 0.01$ and $0.54 \pm 001 \%$ respectively (Table 2 ). These values are agreed with those reported (6.0 and $0.0 \%)$ by Dirar et al. (1985). A remarkable characteristic of Senna obtusifolia fermented leaves is the little change in $\mathrm{pH}$. These values were relativity stable, and varies between 5.87 and 7.22. This was due to the buffering effect of the calcium present in the leaves of S. obtusifolia.

The crude ash content of the kawal was $17.12 \pm 0.01$ and $19.3 \pm 0.01 \%$ (Table 2). These values agreed favourably with 18.0 and $18.74 \%$ value respectively reported in kawal by Mbaiguinam et al.(2005) and Osman et al. (2010). The values obtained for S. obtusifolia fermented leaves show a high level of ash in the fermented leaves than in the fresh leaves. This could be due to the migration of minerals from clay to the leaves during the fermentation.

The crude protein content was between $15.52 \pm 0.09$ and $22.06 \pm 0.01 \%$ (Table 2). The values obtained were however lower than those obtained by Nuha et al., (2010) and Dirar et al., (1985)they reported 26.2\% and $30.20 \%$ for crude protein respectively. The results obtained have been reported by Dirar et al., (1985) and Osman et al., (2010) indicated the crude protein content in 
fermented leaves was higher than in the crude leaves. The difference observed may be explained by difference the crude protein with plant age, locations and environment (Mbaiguinam et al., 2005). Several studies have reported increasing levels of free amino acids, and soluble nitrogen content during alkaline fermentation.

Our results show that the collected kawal samples contained $7.54 \pm 0.43$ to $10.00 \pm$ $0.01 \%$ moisture. However, water activity (aw) of the dried samples is enough to prevent the chemical changes, microorganisms growth and maintain the organoleptic quality during storage time. According to Mbaiguinam et al., (2005) the soil type can affects chemical constituents of the plants.

\section{Microorganisms isolates Numeration}

The results of microbial flora analysis in the collected samples of kawal were presented in Table3.The number of Total Mesophilic Aerobic Flora (TMAF) was between $9.7 \times$ $10^{9}$ and $2.7 \times 10^{11} \mathrm{CFU} / \mathrm{g}$, with an average of $5,7 \times 10^{10} \mathrm{CFU} / \mathrm{g}$. The.Lactic acid bacteria (LAB) levels varied from $1,1 \times 10^{2}$ to $10^{6}$ $\mathrm{CFU} / \mathrm{g}$ with an average of $3.4 \times 10^{5}$ $\mathrm{CFU} / \mathrm{g}$. The presumptive Micrococcus $\mathrm{sp}$ (MI) counts varied from $(<1 \mathrm{CFU} / \mathrm{g})$ to 7 , $4 \times 10^{4} \mathrm{CFU} / \mathrm{g}$ with an average of $4.1 \times 10^{3} \mathrm{CFU} / \mathrm{g}$. The presumptive Staphylococcus sp. (Staph) counts varied from $1,5 \times 10^{3}$ to $3,7 \times 10^{7} \mathrm{CFU} / g$ with an average of $2,5 \times 10^{6} \mathrm{CFU} / \mathrm{g}$, The Bacillus sp between $3.7 \times 10^{8}$ and $9.1 \times 10^{9} \mathrm{CFU} / \mathrm{g}$. Yeasts and molds(YM) counts varied from $(<10 \mathrm{CFU} / \mathrm{g})$ to $4,5 \times 10^{2} \mathrm{CFU} / \mathrm{g}$. Enterobacteria $(\mathrm{EB})$ ranged from $(<10 \mathrm{CFU}$ /g) to1, $6 \times 10^{2}$.

The microbial flora counted and isolated from the different samples of kawal includes different species of microorganisms among theTMAF. Bacillus species occurred most consistently and dominated the fermentation of kawal. This could be due to the ability of the Bacillus species to grow at wide $\mathrm{pH}$ range ( $\mathrm{pH}$ 5.5-8.5) and in addition, the production of several proteolytic enzymes and biologically active compounds enhance the growth of Bacillus species in fermented foods(Ayo, 2010; Mo et al., 2010). Our results correspond to the study conducted by Dirar et al., (1985) showing the Bacillus species as dominant bacteria in kawal samples. Their proteolytic activity with the production of the highest ammonia, characteristic of leguminous, contributes to the development of the texture, flour and organoleptic quality.

The lactic acid bacteria species were isolated and their levels depended on the samples. The variation in the proportion within species of lactic acid bacteria may be due to physicochemical changes during the fermentation on one hand and to the competition between these species on the other hand.

Yeasts and molds as well as enterobacteria are less represented or absent in most of the analyzed samples.In all samples tested Enterobacteria is only represented in two samples and absent in the others. Diar et al., (1985) reported the isolation of Staphylococcus sp. throughout the fermentation of kawal. The Staphylococcus and Micrococcus species could have arisen from handling of the product.

The International Commission on Microbiological Specifications for Foods (ICMSF, 1998) does not recommend microbiological criteria for acceptance or rejection of fermented vegetables. However, the microbial quality for foods are rated as "'good", '"average', "'poor' and "spoiled food'". In this study, the quality of the samples was regarded as"'good'. 


\section{Isolation and Identification of the Bacillus strains}

The morphological examination and cultural characteristics showed variable colony and cell morphology. A total of 108 colonies of bacteria were isolated on Plate Count Agar (PCA) and grouped into 15 groups. Most isolates were large flat, wide spreading, dull surfaced colonies. They are all Gram positive, catalase positive and endospore forming, most of them found to be motile, these indicates that the isolates were belonging to Bacillus genus. To confirm identification, the PCR amplification of the 16S rDNA gene have been used with specific primers to detect Bacillus subtilis group (Wattiau et al., 2001). The amplification of the targeted $16 \mathrm{~S}$ rDNA resulted in a single well defined bands of about 595 bp when match with the band from the DNA Marker (Figure1).

These results confirm that the isolates are belonging to the Bacillus subtilis group. According to morphological and biochemical characterization (Table 4), the isolates showed a high diversity of species within the Bacillus genus, which could belong to the species: $B$. subtilis; $B$. licheniformis, $B$. pumilus and $B$. amyloliquefaciens with a percent similarity of $94.9 \%, 99.9 \%, 97.1 \%$ and $96.6 \%$ respectively obtained by API $20 \mathrm{E}$ using a digitized probabilistic method for Bacillus identification and a search for additional test such as lecithinase, caseinase and amylase(Guech-Lamari and KiraneGacemi, 2012).

Table.1 Primers used in this study

\begin{tabular}{llllc}
\hline Primers & Sequences & Size (bp) & Targettedspecies & References \\
\hline B-K1/F & TCA CCA AGG CRA CGA TGC G & 1114 & Bacillus, Paenibacillus, & (Wattiau et \\
B-K1/R1 & CGT ATT CAC CGC GGC ATG & & Brevibacillus & al., 2001) \\
Bsub5F & AAG TCG AGC GGA CAG ATG G & 595 & Bacillus Subtilisgroup & (Wu et al., \\
Bsub3R & CCA GTT TCC AAT GAC CCT & & $\begin{array}{l}\text { (Bacillus subtilis, } \\
\text { licheniformis, }\end{array}$ & 2006) \\
& CCC C & & amyloliquefaciens, \\
& & & pumilus, atrophaeus) & \\
\hline
\end{tabular}

Table.2 Physico-chemical composition of dried collected kawal samples

\begin{tabular}{lccc}
\hline Parameters & Minimum \pm SD & Mean \pm SD & Maximum \pm SD \\
\hline $\mathrm{pH}$ & $5.87 \pm 0.19$ & $6.47 \pm 0.47$ & $7.22 \pm 0.31$ \\
Titratable acidity $(\%)$ & $0.31 \pm 0.01$ & $0.40 \pm 0.07$ & $0.54 \pm 0.01$ \\
Crude Protein $(\%)$ & $15.52 \pm 0,09$ & $19.23 \pm 2.16$ & $22.06 \pm 0.01$ \\
Total Ash $(\%)$ & $17.12 \pm 0.01$ & $18.73 \pm 0.59$ & $19.3 \pm 0.01$ \\
Moisture $(\%)$ & $7.54 \pm 0.43$ & $8.71 \pm 0.72$ & $10.00 \pm 0.01$ \\
Dry Matter $(\%)$ & $90.00 \pm 0.01$ & $91.29 \pm 0.72$ & $92.46 \pm 0.43$ \\
\hline
\end{tabular}


Table.3 Microorganism count (CFU/g) in twenty collected samples

\begin{tabular}{lccccccc}
\hline \multirow{2}{*}{ Samples } & \multicolumn{7}{c}{ Microorganisms } \\
\cline { 2 - 7 } & TMAF & Bacillus sp & LAB & YM & Staph & MI & EB \\
\hline E1 & $2,7 \times 10^{11}$ & $4,3 \times 10^{9}$ & $2,8 \times 10^{6}$ & $<10$ & $1,1 \times 10^{4}$ & $4,4 \times 10^{2}$ & $<10$ \\
\hline E2 & $3,5 \times 10^{10}$ & $5,1 \times 10^{9}$ & $8,8 \times 10^{5}$ & $<10$ & $1,3 \times 10^{4}$ & $3,9 \times 10^{2}$ & $<10$ \\
\hline E3 & $1,1 \times 10^{10}$ & $3,7 \times 10^{7}$ & $2,4 \times 10^{2}$ & $<10$ & $2,1 \times 10^{5}$ & $<10$ & $<10$ \\
\hline E4 & $2,3 \times 10^{11}$ & $6,7 \times 10^{8}$ & $1,2 \times 10^{6}$ & $<10$ & $2,310^{4}$ & $9,2 \times 10^{2}$ & $<10$ \\
\hline E5 & $2,8 \times 10^{10}$ & $6,1 \times 10^{8}$ & $1,5 \times 10^{2}$ & $<10$ & $2,8 \times 10^{4}$ & $8,4 \times 10^{2}$ & $1,2 \times 10^{2}$ \\
\hline E6 & $4,1 \times 10^{10}$ & $2,8 \times 10^{8}$ & $1,1 \times 10^{2}$ & $<10$ & $2,3 \times 10^{4}$ & $1,8 \times 10^{2}$ & $<10$ \\
\hline E7 & $3,7 \times 10^{10}$ & $2,0 \times 10^{9}$ & $3,7 \times 10^{3}$ & $4,5 \times 10^{2}$ & $1,1 \times 10^{7}$ & $<10$ & $<10$ \\
\hline E8 & $2,1 \times 10^{10}$ & $1,2 \times 10^{9}$ & $1,6 \times 10^{2}$ & $<10$ & $1,2 \times 10^{5}$ & $4,5 \times 10^{2}$ & $<10$ \\
\hline E9 & $7,8 \times 10^{10}$ & $9,4 \times 10^{9}$ & $2,7 \times 10^{4}$ & $<10$ & $1,8 \times 10^{4}$ & $5,4 \times 10^{2}$ & $<10$ \\
\hline E10 & $2,0 \times 10^{10}$ & $6,2 \times 10^{8}$ & $2,1 \times 10^{2}$ & $<30$ & $1,1 \times 10^{4}$ & $2,2 \times 10^{2}$ & $<10$ \\
\hline E11 & $2,2 \times 10^{10}$ & $1,1 \times 10^{9}$ & $3,3 \times 10^{4}$ & $<10$ & $1,5 \times 10^{3}$ & $<10$ & $<10$ \\
\hline E12 & $2,6 \times 10^{10}$ & $1,7 \times 10^{8}$ & $2,8 \times 10^{2}$ & $<10$ & $2,4 \times 10^{4}$ & $<10$ & $1,6 \times 10^{2}$ \\
\hline E13 & $8,7 \times 10^{10}$ & $6,2 \times 10^{8}$ & $4,6 \times 10^{2}$ & $<10$ & $7,8 \times 10^{3}$ & $3,1 \times 10^{2}$ & $<10$ \\
\hline E14 & $7,6 \times 10^{10}$ & $2,1 \times 10^{8}$ & $1,7 \times 10^{3}$ & $<10$ & $1,8 \times 10^{6}$ & $<10$ & $<10$ \\
\hline E15 & $9,7 \times 10^{9}$ & $5,3 \times 10^{7}$ & $6,3 \times 10^{2}$ & $2,2 \times 10^{2}$ & $3,6 \times 10^{4}$ & $<10$ & $<10$ \\
\hline E16 & $6,3 \times 10^{10}$ & $1,2 \times 10^{8}$ & $3,4 \times 10^{5}$ & $<10$ & $5,2 \times 10^{4}$ & $4,1 \times 10^{3}$ & $<10$ \\
\hline E17 & $4,1 \times 10^{10}$ & $4,3 \times 10^{8}$ & $3,5 \times 10^{4}$ & $<10$ & $6,2 \times 10^{3}$ & $<10$ & $<10$ \\
\hline E18 & $9,9 \times 10^{9}$ & $1,7 \times 10^{7}$ & $1,6 \times 10^{6}$ & $<10$ & $1,1 \times 10^{5}$ & $1,1 \times 10^{3}$ & $<10$ \\
\hline E19 & $2,1 \times 10^{10}$ & $2,2 \times 10^{8}$ & $5,1 \times 10^{3}$ & $<10$ & $3,7 \times 10^{7}$ & $7,4 \times 10^{4}$ & $<10$ \\
\hline E20 & $1,5 \times 10^{10}$ & $4,3 \times 10^{8}$ & $2,2 \times 10^{2}$ & $<10$ & $4,4 \times 10^{3}$ & $1,7 \times 10^{2}$ & $<10$
\end{tabular}

TMAF: Total Mesophilic AerobicFlora;LAB: lactic acid bacteria; Staph :Staphylococcus sp; MI : Micrococcus $s p ; \mathbf{E B}$ : Enterobacteria

Fig.1 Electrophoresis gel analysis of PCR-amplified 16S rDNA fragments obtained with Bacillus subtilis Group-Specific Primer

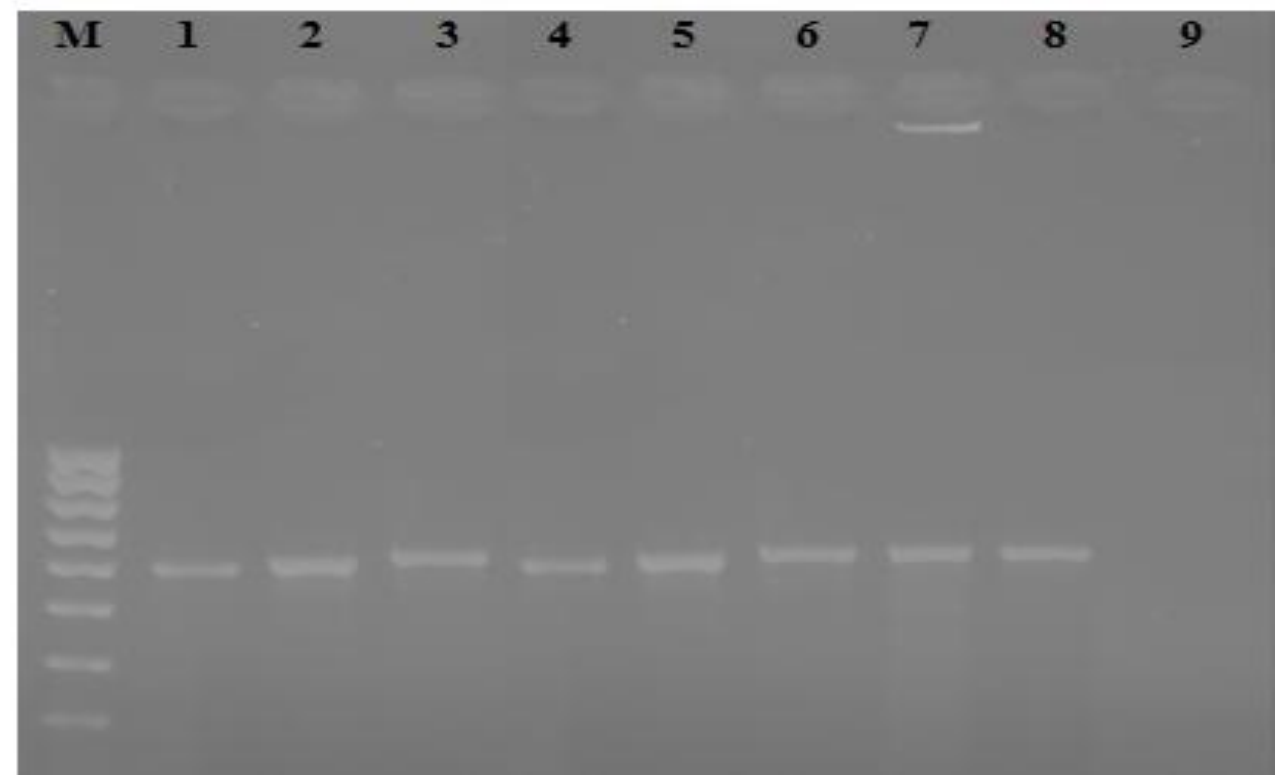

Lanes 1 to 7: Isolates $S_{1}, S_{2}, S_{3}, S_{4}, S_{5}, S_{6} S_{7}$, and $S_{8}$. Lanes 9: Negative control; M: ladder (595 pb) 
Table.4 Biochemical characters of the isolates

\begin{tabular}{|c|c|c|c|c|c|c|c|c|c|c|c|c|c|c|c|}
\hline & & & & & & & & & ains & & & & & & \\
\hline Characteristics & $\mathbf{S}_{1}$ & $\mathbf{S}_{2}$ & $\mathbf{S}_{3}$ & $\mathbf{S}_{\mathbf{4}}$ & $\mathbf{S}_{5}$ & $S_{6}$ & $\mathbf{S}_{7}$ & $\mathbf{S}_{8}$ & $S_{12}$ & $\mathbf{S}_{13}$ & $\mathrm{~S}_{14}$ & $\mathbf{S}_{15}$ & $\mathbf{S}_{34}$ & $\mathbf{S}_{40}$ & $\mathbf{S}_{41}$ \\
\hline ONPG & - & + & \pm & + & + & - & + & + & + & + & + & + & + & - & - \\
\hline $\mathrm{ADH}$ & - & + & - & - & + & + & + & - & - & + & + & + & - & - & - \\
\hline LDC & - & - & - & - & - & - & - & - & - & - & - & - & - & - & - \\
\hline ODC & - & - & - & - & - & - & - & - & - & - & - & - & - & - & - \\
\hline Citrate & - & - & + & + & - & - & + & + & - & + & - & + & - & - & - \\
\hline $\mathrm{H}_{2} \mathrm{~S}$ & - & - & - & - & - & - & - & - & - & - & - & - & - & - & - \\
\hline Urea & - & - & - & - & - & - & - & - & - & - & - & - & - & - & - \\
\hline TDA & - & - & - & - & - & - & - & - & - & - & - & - & - & - & - \\
\hline INDOLE & - & - & - & - & - & - & - & - & - & - & - & - & - & - & - \\
\hline VP & + & + & + & + & + & + & + & + & + & + & + & + & + & + & + \\
\hline Gelatinase & + & + & + & + & + & + & + & + & + & + & + & + & + & + & + \\
\hline Glucose & - & + & + & \pm & + & + & + & \pm & \pm & + & \pm & \pm & + & \pm & + \\
\hline Mannitol & - & + & + & - & + & + & + & \pm & \pm & + & \pm & + & + & + & + \\
\hline Inositol & - & + & + & - & \pm & \pm & \pm & - & \pm & + & \pm & \pm & \pm & - & \pm \\
\hline Sorbitol & - & + & + & - & + & \pm & \pm & - & \pm & + & \pm & \pm & \pm & \pm & \pm \\
\hline Rhamnose & - & - & - & - & - & - & - & - & - & - & - & - & - & - & - \\
\hline Saccharose & - & - & + & \pm & - & + & + & + & + & + & + & \pm & + & + & + \\
\hline Melibiose & - & - & - & - & - & - & - & - & - & - & - & - & - & - & - \\
\hline Amygdaline & - & + & + & \pm & + & + & + & + & + & + & \pm & + & + & + & + \\
\hline Arabinose & - & + & \pm & - & + & - & & - & - & + & \pm & \pm & \pm & - & - \\
\hline Nitrites & + & - & + & - & - & - & - & - & - & - & + & + & - & + & + \\
\hline Oxydase & + & + & + & + & + & - & + & + & - & + & + & + & - & + & + \\
\hline Motility & - & + & + & - & + & - & + & - & + & + & + & - & + & + & + \\
\hline Lecithinase & + & + & + & + & + & - & - & - & + & + & - & - & + & + & + \\
\hline StarchHydrolysis & + & - & + & - & + & + & + & + & + & + & + & + & + & + & + \\
\hline Caseinase & + & + & + & + & + & + & + & + & + & + & + & + & + & + & + \\
\hline Catalase & + & + & + & + & + & + & + & + & + & + & + & + & + & + & + \\
\hline Gram Stain & + & + & + & + & + & + & + & + & + & + & + & + & + & + & + \\
\hline Sporulation & + & + & + & + & + & + & + & + & + & + & + & + & + & + & + \\
\hline
\end{tabular}

+: Positive reaction; -: Negative reaction; \pm : variable.

The result shows that all the isolates of 595 pb were specific to Bacillus subtilis Group. Lanes 1, 2, 3, 4, 5, 6, 7 and 8 belongs to Bacillus subtilis group of isolates $\mathrm{S}_{1}, \mathrm{~S}_{2}, \mathrm{~S}_{3}$, $\mathrm{S}_{4}, \mathrm{~S}_{5}, \mathrm{~S}_{6}, \mathrm{~S}_{7}$, and $\mathrm{S}_{8}$. Lanes 9 was the Negative control; $\mathrm{M}$ is the ladder (595 pb) (Figure 1). This group-specific primer pair (Bsub5F/Bsub3R) capable of amplifying a16S rDNA fragments from Bacillus subtilis group has been developed by Wattiau et al., (2001), to identify Bacillus subtilis, Bacillus licheniformis, Bacillus amyloliquefaciens, Bacillus pumilus, and Bacillus atrophaeus. Bacillus species have been found to be associated with the fermentation of Bikalga and Soumbala, similar food condiments (Ouoba et al., 2003; Savadogo et al., 2011).

In conclusion, microbiological analyzes of different samples of kawal showed that the Total viable counts with the high number among them Bacillus sp., lactic acid 
bacteria, Staphylococcus sp., Micrococcus sp., Yeasts and molds and enterobacteria. Biochemical and molecular characterization of the Bacillus strains isolated from our sample showed a high diversity of species within the genus Bacillus, which could belong to the species: $B$. subtilis; $B$. licheniformis, $B$. pumilus, and $B$. amyloliquefaciens. However, the present work reveals that Bacillus subtilis was dominant in kawal. The Lactic acid bacteria with ability to produce probiotics as well as Bacillus sp strains with their protease activity are important microorganisms which can be used as starter cultures in Senna obtusifolia leaves fermentations. Their addition to kawal may improve safety and stability of the product.

\section{References}

AFNOR. 1986. Méthodes d'essai. Recueil des normes françaises.

AOCS, O. 1990. Tentative Methods of the American Oil Chemists' Society. American Oil Chemists Society Press, Champaign.

Ayo, R. 2010. Phytochemical constituents and bioactivities of the extracts of Cassia nigricans Vahl: A review. $J$. Med. Plants Res., 4(14): 1339-1348.

Battcock, M. 1998. Fermented fruits and vegetables: a global perspective, Food \& Agriculture Org.

Dirar, H.A., Harper, D.B. and Collins, M.A. 1985. Biochemical and microbiological studies on kawal, a meat substitute derived by fermentation of Cassia obtusifolia leaves. J. Sci. Food and Agri., 36(9): 881-892.

Egwim Evans, A.M., Abubakar, Y. and Mainuna, B. 2013. Nigerian indigenous fermented foods: processes and prospects. Mycotoxin and Food Safety in Developing Countries, 153.
Feldsine, P., Abeyta, C. and Andrews, W.H. 2002. AOAC International methods committee guidelines for validation of qualitative and quantitative food microbiological official methods of analysis. J. AOAC Int., 85(5): 11871200.

Foods, I.C.o.M.S.f. 1998. Microbial Ecology of Food Commodities, Blackie Academic \& Professional.

Guech-Lamari, F. and Kirane-Gacemi, D. 2012. Les bactéries sporulées dans les conserves de légumes (petits pois): Recherche et caractérisation phénotypique. Synthèse: Revue des Sciences et de la Technologie, 25(1): 131-139.

Helrich, K. 1990. Official methods of Analysis of the AOAC. Volume 2, Association of Official Analytical Chemists Inc.

Holt, J.G., Krieg, N.R., Sneath, P.H., Staley, J.T. and Williams, S.T. 1994. Bergey's Manual of determinate bacteriology.

ICMSF. 1998. Microbial Ecology of Food Commodities, Blackie Academic \& Professional.

Law, S.V., Abu Bakar, F., Mat Hashim, D. and Abdul Hamid, A. 2011. Popular fermented foods and beverages in Southeast Asia. Int. Food Res. J., 18(2): 475-484.

Mbaiguinam, M., Mahmout, Y., Tarkodjiel, M., Delobel, B. and Bessiere, J.-M. 2005. Constituents of Kawal, fermented Cassia obtusifolia leaves, a traditional food from Chad. African $J$. Biotechnol., 4(10).

Mo, A.Y., Kwon, B., Kamala-Kannan, S., Lee, K.J., Oh, B.T., Kim, D.H., Yang, M.S., Kim, J.H. and Park, S.M. 2010. Isolation and characterization of Bacillus polyfermenticus isolated from Meju, Korean soybean fermentation starter. World J. Microbiol. Biotechnol., 26(6): 1099-1105. 
Nnam, N. and Obiakor, P. 2003. Effect of fermentation on the nutrient and antinutrient composition of baobab (Adansonia digitata) seeds and rice (Oryza sativa) grains. Ecol. Food and Nutrition, 42(4-5), 265-277.

Nout, M., Beernink, G. and Bonants-van Laarhoven, T. 1987. Growth of Bacillus cereus in soyabean tempeh. Int. J. Food Microbiol., 4(4): 293-301.

Oliver, B. 2005. Medicinal plants in Nigeria. Nigerian college of Arts. In linkinghub, elsevier. com/retrieve/pi.

Osman, N.M., Mohamed Ahmed, I.A. and Babiker, E.E. 2010. Fermentation and cooking of sicklepod (Cassia obtusifolia) leaves: changes in chemical and amino acid composition, antinutrients and protein fractions and digestibility. Int. J. Food Sci. Technol., 45(1): 124-132.

Ouoba, L., Cantor, M., Diawara, B., Traore, A. and Jakobsen, M. 2003. Degradation of African locust bean oil by Bacillus subtilis and Bacillus pumilus isolated from soumbala, a fermented African locust bean condiment. J. Appl. Microbiol., 95(4): 868-873.

Savadogo, A., Ilboudo, J.A., Gnankine, O. and Traore, A.S. 2011. Numeration and Identification of thermotolerant endospore-forming Bacillus from two fermented condiments Bikalga and
Soumbala. Adv. Environ. Biol., 29602967.

Sawadogo-Lingani, H., Diawara, B., Traore, A. and Jakobsen, M. 2008. Technological properties of Lactobacillus fermentum involved in the processing of dolo and pito, West African sorghum beers, for the selection of starter cultures. J. Appl. Microbiol., 104(3): 873-882.

Sofowora, A. 2008. Medicinal plants and traditional medicine in Africa, 3rd Edn., Spectrum, Ibadan, Nigeria, pp: 199-204.

Temmerman, R., Pot, B., Huys, G. and Swings, J. 2003. Identification and antibiotic susceptibility of bacterial isolates from probiotic products. Int. $J$. Food Microbiol., 81(1): 1-10.

Wattiau, P., Renard, M.-E., Ledent, P., Debois, V., Blackman, G. and Agathos, S. 2001. A PCR test to identify Bacillus subtilis and closely related species and its application to the monitoring of wastewater biotreatment. Appl. Microbiol. Biotechnol., 56(5-6): 816-819.

Wu, X.Y., Walker, M.J., Hornitzky, M. and Chin, J. 2006. Development of a group-specific PCR combined with ARDRA for the identification of Bacillus species of environmental significance. J. Microbiol. Methods, 64(1): 107-119.

\section{How to cite this article:}

Abakar Idriss Lawane, Savadogo Aly, Tapsoba François, Guira Flibert and Traore Yves. 2016. Identification and Biochemical Analysis of Microorganisms involved in the Fermentation of Kawal-A Traditional Fermented Sicklepod Leaves (Senna obtusifolia). Int.J.Curr.Microbiol.App.Sci. 5(9): 261-270. doi: http://dx.doi.org/10.20546/ijcmas.2016.509.029 